\title{
ANALISIS KURIKULUM 2013 TINGKAT SEKOLAH DASAR DI SDN KP. BULAK III PAMULANG
}

\author{
Aldi Sutisna ${ }^{1}$, Rifdah Fauziah ${ }^{2}$, Putri Indah Lestari ${ }^{3}$ \\ Universitas Muhammadiyah Tangerang \\ aldi.sutisna@umt.ac.id,rifdah.fauziah@umt.ac.id
}

\begin{abstract}
This research was conducted because the process of implementing the 2013 curriculum at SD Negeri Kp. Bulak. III Pamulang has not been optimal, so learning is not optimal due to the lack of several technological tools that support the learning process in the 2013 curriculum. The purpose of this study is to determine the implementation process, and assessment. This research is a qualitative descriptive study. The subjects of this study were grade $1-6$ teachers at SDN Kp. Bulak III Pamulang. While the object of his research is the implementation of the 2013 curriculum learning process in these elementary schools. Data collection techniques were obtained through observation and interviews. The data analysis technique uses the steps of reduction, presentation and conclusion drawing. The results showed that the implementation of the 2013 curriculum learning process in SDN Bp. Bulak. III Pamulang, Pamulang Subdistrict, South Tangerang City was as follows: (1). Planning has gone according to the rules of the learning material. (2). The learning process in class is in accordance with the lesson plan, but there are still obstacles in time management and learning media. (3). Assessment has not gone well because the implementation has used thematic, but in its assessment the teacher must conduct an assessment per subject.
\end{abstract}

Keywords: Learning Analysis, Curriculum 2013

\begin{abstract}
Abstrak: Penelitian ini dilaksanakan karena proses pelaksanaan kurikulum 2013 di SD Negeri Kp. Bulak III Pamulang belum optimal, sehingga pembelajaran menjadi tidak maksimal karena kurang nya beberapa alat teknologi yang mendukung proses pembelajaran pada kurikulum 2013. Tujuan dari penelitian ini adalah untuk mengetahui proses pelaksanaan, dan penilaian. Penelitian ini merupakan penelitian deskriptif kualitatif. Subyek penelitian ini adalah guru kelas $1-6$ di SDN Kp. Bulak III Pamulang. Sedangkan objek penelitian nya adalah pelaksanaan proses pembelajaran kurikulum 2013 di Sekolah dasar tersebut. Teknik pengumpulan data diperoleh melalui observasi dan wawancara. Teknik analisis data menggunakan langkah reduksi, penyajian dan penarikan kesimpulan. Hasil penelitian menunjukan bahwa pelaksanaan proses pembelajaran kurikulum 2013 di SDN Kp.Bulak III Pamulang Kecamatan Pamulang Kota Tangerang Selatan adalah sebagai berikut : (1). Perencanaan sudah berjalan sesuai kaidah materi pembelajaran. (2). Pelaksanaan proses pembelajaran dikelas sudah sesuai dengan RPP, namun masih terdapat kendala dalam manajemen waktu dan media pembelajaran. (3). Penilaian belum berjalan dengan baik karena pada pelaksanaan sudah menggunakan tematik, namun dalam penilain nya guru harus melakukan penilaian per mata pelajaran.
\end{abstract}

Kata Kunci : Analisis Pembelajaran, Kurikulum 2013

Fondatia : Jurnal Pendidikan Dasar

Volume 4, Nomor 1, Maret 2020; 95-109

https://ejournal.stitpn.ac.id/index.php/fondatia 


\section{PENDAHULUAN}

Pembelajaran Kurikulum 2013 Merupakan aktualisasi kurikulum dalam pembelajaran dan pembentukan komptensi serta karakter peserta didik. Kurikulum 2013 akan menghasilkan insan Indonesia yang produktif, kreatif, inovatif dan afektif melalui penguatan sikap, keterampilan dan pengetahuan yang terintegrasi. Berdasarkan pengertian tersebut jelas bahwa kurikulum merupakan inti dari proses pendidikan. Kurikulum harus memuat rumusah yang harus dicapai, pengalaman belajar yang harus dimiliki oleh setiap siswa, serta strategi cara yang dapat dikembangkan.

Pembelajaran kurikulum 2013 akan memberikan makna substansial terhadap mata pelajaran Pendidikan Pancasila dan kewarganegaraan, Bahasa Indonesia, Matematika, Seni Budaya dan Prakarya, serta Pendidikan Jasmani, Olahraga dan Kesehatan. Disinilah Kompetensi Dasar dari Ilmu Pengetahuan Alam dan Ilmu Pengetahuan Sosial yang diorganisasikan kedalam mata pelajaran lain memiliki peran penting sebagai pengikat dan pengembangan Kompetensi Dasar mata pelajaran lainnya. Kurikulum 2013 dalam pembelajaran di kelas, guru dituntuk untuk lebih kreatif dalam menyampaikan materi kepada siswanya. Selain itu, guru juga dituntut untuk lebih menekankan pada proses, bukan pada hasil. Tujuan dari hal tersebut adalah agar siswa sebagai sasaran utama perubahan kurikulum ini diharapkan akan mampu menjadi pribadi yang berkarakter

Dengan kata lain prinsip yang paling mendasar tentang kurikulum 2013 adalah penekanan pada kemampuan guru mengimplementasikan proses pembelajaran yang otentik, menantang dan bermakna bagi peserta didik sehingga dengan demikian dapatlah berkembang potensi peserta didik sesuai dengan apa yang diharapkan oleh tujuan pendidikan nasional. Namun, masih banyak guru yang belum bisa atau masih bingung dalam melaksanakan atau mengimplementasikan kurikulum 2013 itu dalam pembelajaran.

Faktor pendukung dan penghambat kurikululum 2013 antara lain, factor yang mendukung adalah semua tenaga pendidik dan kependidikan SD Negeri Kp. Bulak III Pamulang, wali murid, komite sekolah dan warga sekitar selalu membantu berperan serta baik secara langsung maupun tidak langsung dalam peningkatan 
pendidikan karakter peserta didik. Secara langsung ikut serta dalam rapat pengembangan kurikulum dan kegiatan sekolah. Secara tidak langsung yaitu dengan membiasakan mendidik anak dengan selalu meningkatkan karakter peserta didik.

Factor yang menghambat adalah pengaruh luar sekolah yaitu lingkungan siswa yang merupakan perbatasan kota dan desa yang membuat peserta didik kadang bingung dalam memilih perbuatan yang sesuai dengan karakter bangsa dan yang tidak. Ini mempengaruhi dalam peningkatan pendidikan karakter yaitu proses pendidikan karakter menjadi agak lama dan kurang sesuai dengan pengembangan kurikulum 2013 di SD Negeri Kp. Bulak III Pamulang.

Adapun tujuan dari kurikulum 2013 adalah untuk mempersiapkan manusia Indonesia agar memiliki kemampuan hidup sebagai pribadi dan warga Negara yang beriman, produktif, kreatif, inovatif, dan afektif serta mampu berkontribusi pada kehidupan bermasyarakat, berbangsa, dan peradaban dunia.

Pada kenyataannya kegiatan pembelajaran kurikulum 2013 belum berjalan sesuai dengan apa yang diharapkan oleh pemerintah. Berbagai kendala seperti guru yang kesulitan dalam pembuatan Rencana Pembelajaran, penggunaan alat teknologi yang kurang memadai sampai kesulitan dalam melakukan penilaian kurikulum 2013 menjadi kendala utama dalam implementasi kurikulum ini.

SD Negeri Kp. Bulak III Pamulang adalah salah satu Sekolah percontohan implementasi kurikulum 2013 di kecamatan Pamulang. Sekolah ini sudah melaksanakan pergantian kurikulum dari tahun 2013. Namun, berdasarkan hasil observasi yang peneliti lakukan, peneliti menemukan beberapa kendala dalam pelaksanaan kurikulum 2013. Hasil observasi menemukan bahwa guru belum siap dengan perubahan kurikulum ini. Hal ini terlihat ketika dalam perencanaannya guru masih kesulitan dalam pembuatan RPP, Guru SD Negeri Kp Bulak III Pamulang juga terlihat mengalami kendala dalam pembelajaran, seperti kesulitan mengorelasikan mata pelajaran dengan tema dan menggunakan ceramah. Kesulitan yang dialami guru dalam menggunakan alat teknologi dalam proses pembelajaran dan kesulitan juga terlihat dalam penialain kurikulum 2013, seperti lamanya waktu penyusunan laporan hasil belajar siswa. 
Berdasarkan fakta tersebut, maka diperlukan adanya pengkajian dalam pelaksanaan kurikulum 2013 di SD tersebut. Oleh karena itu, peneliti memilih sekolah yang telah melaksanakan kurikulum 2013 yaitu SD Negeri Kp Bulak III Pamulang Kota Tangerang Selatan sebagai tempat penelitian.

\section{METODE PENELITIAN}

\section{Jenis Penelitian}

Penelitian ini merupakan penelitian kualitatif. Penelitian adalah proses mengumpulkan dan menganalisis data atau informasi secara sistematis sehingga menghasilkan kesimpulan yang sah. (Sekaran, 2003) "Penelitian juga dapat diartikan sebagai suatu kegiatan yang terorganisir, sistematis, berdasarkan data, dilakukan secara kritis, objektif, ilmiah untuk memaparkan jawaban atau pemahaman yang lebih mendalam atas suatu masalah.” Penelitian kualitatif merupakan suatu pendekatan atau penelusuran untuk mengeksplorasi dan memahami suatu gejala sentral. (Creswell, 2008). Sedangkan tujuan penelitian deskriptif ini adalah untuk membantu pembaca mengetahui apa yang terjadi dilingkungan di bawah pengamatan, seperti apa pandangan partisipan yang berada di latar penelitian, dan seperti apa aktivitas yang terjadi di latar penelitian (Emzir, 2012:174). Dengan menggunakan peneliti deskriptif kualitatif, peneliti dapat mengidentifikasi masalah - masalah, keadaan dan praktik praktik yang sedang berlangsung di masyarakat. Adapaun penelitian kualitatif sebagai Human Instrument berfungsi sebagai menetapkan fokus penelitian, memilih informan sebagai sumber data, menilai kualitas data, analisis data, menafsirkan data dan membuat kesimpulan atas temuannya (Sugiyono, 2017).

\section{Tempat dan Waktu Penelitian}

Penelitian dilakukan di SD Negeri Kp Bulak III Pamulang Kecamatan Pamulang. Penelitian ini dilaksanakan pada bulan November 2019.

\section{Subjek dan Objek Penelitian}

Subjek dalam penelitian ini adalah guru kelas 1 sampai dengan kelas 6 Sekolah Dasar Negeri Kp. Bulak III Pamulang. Penelitian ini diambil untuk memperoleh 
informasi secara maksimal. Sedangkan objek penelitiannya adalah untuk pelaksanaan proses pembelajaran kurikulum 2013 di Sekolah Dasar Tersebut.

\section{Teknik dan Instrumen Pengumpulan Data}

1. Teknik Pengumpulan Data

Pengumpulan data bisa dilakukan hearts berbagai pengaturan, berbagai sumber, dan berbagai cara. Bisa dilihat dari settingnya data bisa dikumpulkan pada pengaturan dilihat dari sumber datanya maka mengumpulkan data dapat menggunakan sumber primer dan sumber sekunder. Sumber primer adalah sumber data yang langsung memberikan data kepada pengumpul data, dan sumber sekunder adalah sumber yang tidak langsung memberikan data untuk pengumpul data. Selanjutnya jika dilihat dari segi empat cara atau tekniknya, maka teknik melewati data bisa dilakukan dengan observasi, wawancara sebagai hasil penelitian dalam proses pembelajaran kurikulum 2013.

a. Observasi

Observasi adalah teknik pengumpulan data yang paling lazim dipakai dalam penelitian kualitatif. Dengan observasi partisipatif, peneliti harus banyak memainkan peran selayaknya yang dilakukan oleh subyek penelitian, pada situasi yang sama atau berbeda. Adapun menurut (Adler \& Adler, 1987:78, Anderson \& Mayer, 1982 : 32, Denzin \& Lincoln, 2009 :523) Observasi merupakan kegiatan ilmiah empiris yang berdasarkan fakta - fakta lapangan maupun teks.

Ada beberapa startegi yang mungkin dapat dilakukan seorang peneliti untuk memainkan perannya mengikuti kegiatan subjek, antara lain : Pertama, peneliti mendeklarasikan bahwa dia ikut memikul tanggung jawab, Kedua, observasi dilakukan melalui layar monitor, Ketiga, peneliti hanya berperan sebagai pengamat. Keempat, atas kesepekatan antara peneliti dengan subjek penelitian, peneliti terlibat secara lengkap dan secara utuh berperan serta dalam kegiatan kegiatan subjek, dengan hanya sedikit perbedaan antara peneliti dan subjek itu.

b. Wawancara

Wawancara merupakan sebuah percakapan antara dua orang atau lebih, yang pertanyaan nya diajukan oleh peneliti kepada subjek atau sekelompok subjek 
penelitian untuk dijawab. Pada penelitian kualitatif, wawancara mendalam dapat dilakukan dengan dua cara.

Pertama, wawancara sebagai strategi utama dalam mengumpulkan data. Pada konteks ini, catatan data lapangan yang diperoleh berupa transkrip wawancara.

Kedua, wawancara sebagai strategi penunjang teknik lain dalam mengumpulkan data, seperti observasi partisipan, analisis dokumen, dan fotografi.

Berdasarkan strukturnya, pada penelitian kualitatif ada dua jenis wawancara. Pertama, wawancara relative tertutup. Pada wawancara dengan format ini, pertanyaan - pertanyaan difokuskan pada topic - topic khusus atau umum. Kedua, wawancara yang terbuka. Pada wawancara ini, peneliti memberikan kebebasan diri dan mendorongnya untuk berbicara secara luas dan mendalam.

1) Pedoman Wawancara

Pedoman wawancara berisi tentang aspek - aspek yang berkaitan dengan hal hal yang akan diwawancarai (Bapak/Ibu guru sebagai narasumber). Adapun kisi kisi pedoman wawancara pelaksanaan proses pembelajaran kurikulum 2013 di SD Negeri Kp. Bulak III Pamulang.

Tabel 1.

\begin{tabular}{|c|c|c|}
\hline $\mathrm{No}$ & $\begin{array}{l}\text { Aspek yang di } \\
\text { pertanyakan }\end{array}$ & Fokus dari pertanyaan \\
\hline 1 & $\begin{array}{l}\text { Perencanaan } \\
\text { Pembelajaran } \\
\text { Tematik } \\
\text { Kurikulum } \\
2013\end{array}$ & $\begin{array}{l}\text { a. Bagaimana Bapak/Ibu guru dalam menyusun } \\
\text { silabus dalam pembelajaran tematik? } \\
\text { b. Bagaimana Bapak/Ibu guru dalam menyusun } \\
\text { rencana pelaksanaan pembelajaran kurikulum } \\
\text { 2013? } \\
\text { c. Apakah semua aspek atau komponen yang } \\
\text { terdapat disilabus sudah berjalan dengan baik } \\
\text { dengan mengacu dari tahun sebelumnya? } \\
\text { d. Apakah dalam proses pembelajaran sudah } \\
\text { memenuhi standar aturan yang terdapat pada } \\
\text { rencana pelaksanaan pembelajaran dan } \\
\text { silabus? }\end{array}$ \\
\hline 2 & $\begin{array}{l}\text { Pelaksanaan } \\
\text { Pembelajaran } \\
\text { Tematik }\end{array}$ & $\begin{array}{l}\text { a. Apakah Bapak/Ibu guru mengalami kesulitan } \\
\text { dengan kegiatan kegiatan dalam proses } \\
\text { pembelajaran kurikulum } 2013 \text { yang mengacu }\end{array}$ \\
\hline
\end{tabular}




\begin{tabular}{|c|c|c|}
\hline & $\begin{array}{l}\text { Kurikulum } \\
2013\end{array}$ & $\begin{array}{l}\text { pada RPP? } \\
\text { b. Apakah Bapak/Ibu guru sudah menjalani } \\
\text { aturan - aturan yang terdapat pada RPP yang } \\
\text { mengacu kepada pembelajaran tematik } \\
\text { c. Bagaimana perbedaan yang Bapak/Ibu } \\
\text { Rasakan ketika menerapkan Kurikulum } 2013 \\
\text { dengan KTSP dalam proses pembelajaran di } \\
\text { kelas? }\end{array}$ \\
\hline & $\begin{array}{l}\text { Penggunaan } \\
\text { Media } \\
\text { Pembelajaran } \\
\text { Dalam Proses } \\
\text { Pembelajaran }\end{array}$ & $\begin{array}{l}\text { a. Apakah media pembelajaran sangat } \\
\text { membantu dalam proses pembelajaran } \\
\text { guruyang terdapat pada Kurikulum } 2013 \\
\text { b. Apakah Bapak/Ibu guru mengalami kesulitan } \\
\text { dalam menggunakan media pembelajaran } \\
\text { c. Bagaiaman respon dari para siswa ketika } \\
\text { Bapak/Ibu guru menggunakan media } \\
\text { pembelajaran? }\end{array}$ \\
\hline 4 & $\begin{array}{l}\text { Penilaian } \\
\text { Pembelajaran } \\
\text { Tematik } \\
\text { Kurikulum } \\
2013\end{array}$ & $\begin{array}{l}\text { a. Dalam Kurikulum } 2013 \text { menekankan } \\
\text { penialaian Kognitif, Afektif, dan } \\
\text { Psikomotorik, jenis penilaian apa yang selama } \\
\text { ini kurang maksimal dari proses } \\
\text { pembelajaran? } \\
\text { b. Dalam kurikulum 2013, Penilaian dan } \\
\text { penulisan laporan hasil belajar dibuat bukan } \\
\text { secara manual tulis tangan, melainkan sudah } \\
\text { dalam bentuk ketikan, apakah hal tersebut } \\
\text { Bapak/Ibu guru mengalami kesulitan dalam } \\
\text { proses pembuatan nya? }\end{array}$ \\
\hline
\end{tabular}

2) Pedoman Observasi

Pada observasi yang akan dilakukan oleh peneliti, peneliti akan mengobservasi pelaksanaan kurikulum 2013 di SD Negeri Kp. Bulak III.

2. Instrumen Penelitian

Menurut Zuriah (2009: 198), "Instrumen penelitian merupakan alat bantu bagi peneliti dalam mengumpulkan data “. Tujuan pembuatan instrument ini adalah untuk mengetahui pelaksanaan kurikulum 2013 di SD Negeri Kp. Bulak III Pamulang. Berdasarkan teknik yang digunakan untuk mengumpulkan data yaitu, 
observasi, dokumentasi, dan wawancara, maka instrument yang dipakai peneliti adalah pedoman observasi dan pedoman wawncara. Dengan demikian pedoman wawancara dan pedoman observasi dibuat untuk mengukur aspek sebagai berikut :

a. Membuat kisi - kisi instrument penelitian pelaksanaan kurikulum 2013 di SD Negeri Kp. Bulak III.

Tabel 2 Kisi - kisi observasi pelaksanaan proses pembelejaran kurikulum 2013

\begin{tabular}{|c|c|c|c|}
\hline $\begin{array}{c}\text { Variab } \\
\text { el }\end{array}$ & $\begin{array}{c}\text { Sub } \\
\text { Variabel }\end{array}$ & Indikator & $\begin{array}{c}\text { Jumlah } \\
\text { Pertanya } \\
\text { an Soal }\end{array}$ \\
\hline $\begin{array}{l}\text { Pelaks } \\
\text { anaan } \\
\text { proses } \\
\text { pembe } \\
\text { lajaran } \\
\text { kuriku } \\
\text { lum } \\
2013 \\
\text { di SD }\end{array}$ & 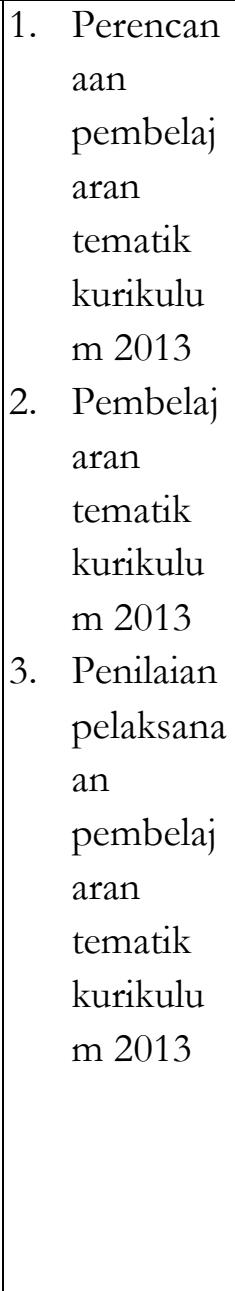 & $\begin{array}{ll}\text { a. Kegiatan mengidentifikasi } \\
\text { tema / subtema } \\
\text { b. Kegiatan merumuskan } \\
\text { indicator } \\
\text { c. Kegiatan mengidentifikasi } \\
\text { perbedaan kurikulum baru } \\
\text { dan lama } \\
\text { d. Kegiatan memilih sumber } \\
\text { belajar } \\
\text { a. } \\
\text { Mengidentifikasi } \\
\text { perumusan masalah dalam } \\
\text { pembelajaran tematik } \\
\text { b. Mengidentifikasi } \\
\text { permasalahan } \\
\text { penggunaan dalam } \\
\text { pembelajaran } \\
\text { c. Kegiatan stimulus respon } \\
\text { dari } \\
\text { kurikulum dan media } \\
\text { pembelajaran } \\
\text { a. Kegiatan penilaian oleh } \\
\text { guru } \\
\text { b. Kegiatan penilaian laporan } \\
\text { hasil belajar }\end{array}$ & 4 \\
\hline
\end{tabular}




\section{Keabsahan Data}

Keabsahan data suatu penelitian juga dapat dicapai dengan proses pengumpulan data yang tepat. Salah satu caranya adalah dengan proses triangulasi. Triangulasi adalah teknik pengumpulan data yang bersifat menggabungkan dari berbagai teknik pengumpulan data dan sumber data yang telah ada.

Keabsahan data penelitian kualitatif menggunakan istilah berbeda meliputi, credibility (Validitas interbal), transferability (validitas eksternal), dependability (reliabilitas) dan confirmability (objektifitas) (Sugiyono, 2011 : 366). Penelitian ini menggunakan uji kredibilitas (credibility) dengan melakukan triangulasi dan menggunakan bahan refernsi.

Menurut susan stainback dalam sugiyono (2011: 330) menyatakan bahwa tujuan dari triangulasi bukan untuk mencari kebenaran tentang beberapa fenomena, tetapi lebih pada peningkatan pemahaman peneliti terhadap apa yang telah ditemukan.

Triangulasi data yang dipakai oleh peneliti merupakan triangulasi sumber yaitu pengumpulan data dengan berbagai macam - macam cara pada sumber yang sama seperti yang terlihat pada gambar.

Menurut Patton (1987) dalam moleong (2013 : 330), Tringulasi dengan sumber berarti membandingkan dan mengecek balik derajat kepercayaan suatu informasi yang diperoleh melalui waktu dan alat yang berbeda dalam penelitian kualitatif.

\section{Teknik Analisis Data}

Teknik analisis data dalam penelitian ini menggunakan teknik analisis kualitatif. Menurut Miles and Huberman, aktivitas dalam analisis data kualitatif dilakukan secara interaktif dan berlangsung secara terus menerus sampai tuntas, sehingga datanya sudah jenuh (Sugiyono 2011 : 337). Aktivitas dalam analisis data, yaitu data reduction (Reduksi data), data display (penyajian data), dan conclusion drawing/verification (Penarikan kesimpulan).

1. Data reduction (reduksi data)

Data yang diperoleh dari penelitian beragam, apalagi dengan memadukan beberapa teknik. Mereduksi data berarti merangkum, memilih hal - hal yang 
pokok, memfokuskan pada hal - hal yang penting, dicari tema dan polanya dan membuang yang tidak perlu.

2. Data display (penyajian data)

Dalam penelitian kualitatif, penyajian data bisa dilakukan dalam bentuk uraian singkat, bagan, hubungan antar teori dan sebagainya.

3. Conclusion (penarikan kesimpulan)

Kesimpulan dalam penelitian kualitatif dapat berupa deskripsi atau gambaran suatu obyek yang sebelumnya masih remang - remang sehingga setelah diteliti menjadi jelas.

Berdasarkan pengertian di atas, dalam penelitian ini menggunakan teknik analisis data kualitatif. Terdapat tiga jalur analisis data yaitu data reduction (reduksi data), data display (penyajian data), dan conclusion (penarikan kesimpulan).

Data reduction, pada tahap ini dilakukan pemilihan tentang relevan tidaknya antara data dengan tujuan penelitian. Data yang diperoleh dari penelitian yang beragam dengan memadukan beberapa teknik. Informasi dari lapangan sebagai bahan mentah yang kemudian diringkas, disusun lebih sistematis, serta ditonjolkan pokok - pokok yang penting sehingga lebih mudah dikendalikan. Setelah tahap mereduksi data selesai dilakukan, kemudian dilanjutkan dengan display data untuk dapat melihat gambaran keseluruhan atau bagian Bagian tertentu dari gambar keseluruhan. Pada tahap ini peneliti berupaya mengklasifikasikan dan menyajikan data sesuai dengan pokok permasalahan yang diawali dengan pengkodean pada setiap sub pokok permasalahan. Untuk memudahkan memperoleh kesimpulan dari lapangan, maka penyajian data bisa dilakukan dalam bentuk uraian singkat, bagan, serta hubungan antar teori.

Tahap ketiga dalam teknik analisis data menurut Miles and Huberman adalah Conclusion drawing/verification (penarikan kesimpulan) Kegiatan yang dimaksudkan untuk mencari makna data yang dikumpulkan dengan mencari hubungan, persamaan atau perbedaan. Penarikan kesimpulan dilakukan dengan jalan membandingkan kesesuaian pernyataan dari subyek penelitian dengan makna yang terkadnung dengan konsep - konsep dasar dalam penelitian tersebut. Kesimpulan 
dalam penelitian kualitatif dapat berupa deskripsi atau gambaran suatu objek yang sehingga setelah diteliti menjadi jelas.

\section{HASIL PENELITIAN DAN PEMBAHASAN}

1. Deskripsi umum lokasi penelitian dan narasumber

a. Deskripsi Keadaan Lokasi

Lokasi yang digunakan peneliti adalah di Sekolah Dasar Negeri Kp. Bulak III Pamulang, Kota Tangerang Selatan merupakan sekolah yang masih menggunakan kurikulum 2013. Lokasi penelitian berada pada wilayah yang kurang strategis. SD Negeri Kp. Bulak III berada di jalan Kav Keuangan dekat dengan komplek Mako Brimob. Peneliti tidak hanya mengambil data dari kepala sekolah melainkan dari guru kelas juga.

b. Profil Narasumber/ Informan

Narasumber atau responden dalam penelitian ini adalah Kepala Sekolah SD Negeri Kp.Bulak III dan guru kelas 1,2,3,4,5,6.

2. Analisis Data Pelaksanaan Proses Pembelajaran Kurikulum 2013

Analisis data lebih difokuskan selama proses dilapangan bersama dengan pengumpulan data. Adapaun pemeroleh data melalui dua teknik yaitu observasi dan wawancara langsung dengan narasumber. Analisis yang dilakukan selama dilapangan menurut model Miles dan Huberman (Sugiyono, 2011 : 337) ada tiga tahap, yaitu reduksi data (data reduction), penyajian data (display data), dan verifikasi (Conclusion drawing). Data diperoleh berdasarkan tiga teknik pengumpulan yaitu dokumentasi, observasi dan wawancara. Dalam analisis ini penelitian bagi dalam perencanaan, pelaksanaan, pembelajaran dikelas, dan penelitian.

a. Pelaksanaan pembelajaran kurikulum 2013 di SD Negeri Kp. Bulak III Pamulang data mengenai perencanaan, pelaksanaan, dan penilaian pembelajaran tematik diperoleh melalui dokumentasi observasi dan wawancara. 
1) Perencanaan

Berdasarkan hasil observasi perencanaan pada kelas 1,2,3,4,5,6 pada tabel 4 (terlampir) komponen pemahaman guru tentang buku pedoman guru dan buku pedoman siswa yaitu guru sudah memahami kelengkapan buku dan memahami hubungan fungsional buku pedoman guru dan buku teks pelajaran dalam proses pembelajaran dengan baik. Guru juga sudah memahami kelengkapan buku teks pelajaran dan hubungan aktifitas pembelajaran dengan sumber dan media pembelajaran.

Tahap perencanaan pembelajaran kurikulum 2013 si SD Negeri Kp.Bulak III Pamulang sudah sesuai dengan kaidah dengan kurikulum 2013. Karena dalam pembuatan RPP sudah memenuhi komponen - komponen Kurikulum 2013, yaitu identitas tema/subtema, perumusan indicator, perumusan tujuan pembelajaran, pemilihan materi ajaran, pemilihan sumber belajar, model pembelajaran, scenario pembelajaran, dan penelitian serta belum begitu menggunakan media pembelajaran sebagai proses belajar dikelas

2) Pelaksanaan Pembelajaran Tematik Kurikulum 2013

Tahap ini merupakan tahap penerapan yang sudah dibuat oleh guru dalam pelaksanaan. dalam proses pembelajaran guru jarang sekali menggunakan media pembelajaran sebagai proses pembelajaran yang diajarkan kepada siswa.

a. Pelaksanaan Pembelajaran Kurikulum 2013 kelas 1 SD Negeri Kp. Bulak III Pamulang

Berdasarkan hasil observasi menyatakan, bahwa guru sudah melakukan proses pembelajaran sesuai aturan RPP namun seringkali tidak menggunakan media pembelajaran sebagai proses belajar yang memudahkan siswa.

b. Pelaksanaan Pembelajaran Kurikulum 2013 kelas 2 SD Negeri Kp. Bulak III Pamulang

Menurut hasil observasi dan wawancara tidak berbeda jauh dengan kelas 1 . Pembelajaran tematik kurikulum 2013 sudah berjalan baik namun jarang sekali dalam hal ini menggunakan media pembelajaran sebagai proses pembelajaran. 
c. Pelaksanaan Pembelajaran Kurikulum 2013 kelas 3 SD Negeri Kp. Bulak III Pamulang

Berdasarkan penelitian melalui observasi dan wawancara, guru kelas 3 belum memahami dalam pelaksanaan pembelajran tematik, seperti sub tema dan lain sebagainya dan juga jarang sekali dalam penggunaan media pembelajaran.

d. Pelaksanaan Pembelajaran Kurikulum 2013 kelas 4 SD Negeri Kp. Bulak III Pamulang

Dari hasil observasi dan wawncara, guru kelas 4 sudah memahami pembelajaran tematik 2013 ia begitu menguasai aturan aturan yang terdapat dalam RPP dan juga menggunakan media pembelajaran sebagi proses belajar.

e. Pelaksanaan Pembelajaran Kurikulum 2013 kelas SD Negeri Kp. Bulak III Pamulang

Menurut hasil observasi dan wawancara, guru kelas 5 sangat baik dalam memahami aturan yang terdapat di RPP dan begitu menguasai pembelajaran Tematik kurikulum 2013 dan selalu menggunakan media pembelajaran dalam proses pembelajaran.

f. Pelaksanaan Pembelajaran Kurikulum 2013 kelas 6 SD Negeri Kp. Bulak III Pamulang

Berdasarkan hasil observasi dan wawancara, guru kelas 6 juga sangat baik dalam memahami aturan yang terdapat di RPP dan begitu menguasai pembelajaran tema dan juga menggunakan media pembelajaran.

\section{PEMBAHASAN}

1. Perencanaan

Kegiatan perencanaan pembelajaran di SD Negeri Kp. Bulak III Pamulang kelas 1,2,3,4,5,6 sudah hampir sesuai dengan kaidah kurikulum 2013 yang tercantum pada permendikbud No. 81A tahun 2013. Guru juga sudah mampu memahami kelengkapan buku dan memahami hubungan fungsional buku pedoman guru dan buku tek pelajaran dalam proses pembelajaran dengan baik. Guru - guru di SD Negeri Kp. Bulak III Juga hampir seluruhnya selalu melakukan 
langkah - langkah perencanaan dalam melakukan pembelajaran agar tidak kebingungan dalam proses pembelajaran di kelas.

2. Pelaksanaan

Berdasarkan hasil penelitian, guru di SD Negeri 4 Pamulang sudah melaksanakan pelaksanaan pembelajaran di kelas sesuai dengan RPP yang telah dibuat. Dalam hal ini guru sudah melakukan sesuai kaidah di RPP Hampir seluruhnya. Dalam pelaksanaan kegiatan awal juga guru melakukan nya dengan sangat baik.

Penerapan pendekatan saintifik sudah terlaksana dengan baik pada kelas 4,5,6 karena saat didalam kelas sudah terlihat guru hanya mengarahkan dan siswa yang aktif, selain itu untuk kelas 4,5,6 siswa sudah bisa diajak untuk berfikir kritis yang menjadi salah satu ciri khas dalam pelaksanaan pembelajaran kurikulum 2013.

3. Penilaian

Menurut hasil penelitian di SD Negeri Kp. Bulak III Pamulang, penilaian yang dilakukan guru sudah sesuai kaidah kurikulum 2013 namun ada beberapa guru yang kurang memahami dari sistematika penilaian kurikulum 2013, seperti penilaian laporan hasil belajar yang menggunakan Laptop atau computer, yang kurang dikuasai oleh beberapa guru tentang alat teknolgi tersebut.

\section{KESIMPULAN}

Hasil penelitian menunjukan bahwa guru di SD Negeri Kp. Bulak III Pamulang sudah paham mengenai pembelajaran tematik kurikulum 2013 hanya ada beberapa guru saja yang kurang begitu paham. Secara umum dapat ditarik kesimpulan sebagai berikut :

1. Dalam pembuatan perencanaan, dari hasil observasi yang peneliti laksanakan perencanaan RPP dibuat oleh guru sudah sesuai dengan kaidah aturan yang berlaku.

2. Dalam tahap pelaksanaan pembelajaran guru sudah hampir melakukan pembelajaran sesuai dengan RPP yang telah dibuatnya. Kendala yang guru alami adalah kurangnya waktu dalam proses pembelajaran. 
3. Tahap penilaian beberapa guru mengalami kebingungan dalam melaksanakan proses penialain, penialaian hasil lapor belajar pun guru mengalami banyak kebingungan karena pada kurikulum 2013 menggunakan hasil cetak dalam proses penilaian hasil laporan belajar bukan manual lagi.

\section{DAFTAR PUSTAKA}

Imam Dwi Upayanto. 2017. Pelaksanaan Proses Pembelajaran Kurikulum 2013 SD Negeri 4 Krandengan: Universitas Negeri Yogyakarta.

H. Kosyanto. 2014. Studi Analisis Kurikulum 2013 : Kemenag.

Siti Nurohmah. Pengembangan Kurikulum Dalam Meningkatkan Pendidikan Karakter Di Sekolah Dasar: Dinas Pendidikan Dan Olahraga Pemerintah Kabupaten Bantul

Hasyim Hasanah. Teknik - Teknik Observasi : Fakultas Dakwah dan Komunikasi Universitas Negeri Semarang.

Thalha Alhamid dan Bodur Anufia. 2019. Resume : Instrumen Pengumpulan Data : Sekolah Tinggi Agama Islam Negeri (STAIN) Sorong, 2019.

Sudarwan Danim. Menjadi Peneliti Kualitatif. Bandung: Cv Pustaka Setia.

Durri Andriani, Dkk. Metode Penelitian. Tangerang Selatan: Universitas Terbuka.

Yusep Suryana, Dkk. Seri Peningkatan Kompetensi dan Kinerja Guru Pengembangan Kurikulum. Banten: CV Rizki Aulia.

Sugiyono. Metode Penelitian Pendidikan Pendekatan Kuantitatif, Kualitatif, dan R\&D. Bandung: Alfabeta Bandung.

Mulyasa. Pengembangan dan Implementasi Kurikulum 2013. Bandung: Rosda Buku. Emzir.2012. Metodologi Penelitian Pendidikan. Jakarta : Rajawali Pers. 